\title{
THE EFFECT OF POST-ANAESTHETIC DREAMING ON PATIENT \\ ACCEPTANCE OF KETAMINE ANAESTHESIA: A COMPARISON WITH THIOPENTONE-NITROUS OXIDE ANAESTHESIA
}

\author{
Michael Krestow, M.D. ${ }^{\circ}$
}

Post-ANAESTHETIC DREAMS are a disturbing side effect of ketamine anaesthesia. This dreaming was given only passing notice in the early investigations of ketamine, suggesting perhaps that the disturbance was of little consequence. As time progressed, these disturbances became more appreciated. Corssen et al. ${ }^{1}$ (1968) found a 2.8 per cent incidence of dreams following anaesthetics in which ketamine was used in conjunction with other agents. This paper made no comments on the psychological side effects from the dreams. Clarke et al. ${ }^{2}$ (1970) administered ketamine with nitrous oxide to unpremedicated patients. The study reported 46 per cent of patients had vivid dreams. Galloon ${ }^{3}$ (1971) administered ketamine, in sequence with nitrous oxide oxygen, preceded by diazepam premedication. Twenty-five per cent of the patients dreamed; pleasant dreams predominated. Garfield, et al. ${ }^{4}$ (1972) in a comparative study of ketamine and nitrous oxide oxygen halothane anaesthesia found post anaesthetic illusions after ketamine. This finding did affect the acceptability of ketamine for future surgery in a few of their patients. Knox et al..$^{5}$ concluded that this agent was not popular with their patients. Fifty-six per cent of their patients would refuse a ketamine anaesthetic in future.

Contrasting ketamine to thiopentone nitrous oxide oxygen, one finds that there are post-anaesthetic psychomimetic disturbances with the latter anaesthetic technique; Wilson \& Turner $^{6}$ in their study in 1970 report an incidence of 30 per cent; Bryce et al. ${ }^{7}$ in 1970 one of 43.8 per cent; Harris, et al. ${ }^{8}$ in 1971 found an even higher frequency of dreaming. Crawford, ${ }^{9}$ however, reported that only 9 per cent of his patients dreamed. His patients were premedicated with chloradiazepoxide, and hyoscine. None of these latter investigators commented on the effect of these psychomimetic disturbances on the future acceptance of thiopentone-nitrous oxide oxygen by their patients. Our initial clinical experience with ketamine suggested a higher percentage of psychic disturbances in the recovery room than following the more conventional agents. We decided, therefore, to compare ketamine with thiopentone-nitrous oxide-oxygen anaesthesia with the intent of exploring what effect the patient's psychomimetic disturbances - usually described as dreams - have on the acceptance by the patient of the same anaesthetic on future occasions. We assumed that:

(a) the incidence of unpleasant dreams would be higher following ketamine than after thiopentone-nitrous oxide anaesthesia.

(b) the rejection rate for ketamine, an anaesthetic of choice for future surgery, would be higher than the rejection rate for the thiopentone-nitrous oxide technique as a result of the higher incidence of unpleasant dreams.

'Department of Anaesthesia, University of Toronto and The Toronto Western Hospital.

Canad. Anaesth. Soc. J., vol. 21, no. 4, July 1974 


\section{METHOD \& MATERIAL}

A prospective study was made of 100 consecutive patients booked for therapeutic abortion. Patients were all group 1 in the A.S.A. classification of physical status. No patient showed psychotic disturbance before operation.

In alternating order the patients received either ketamine $2 \mathrm{mg}$ per $\mathrm{kgm}$ at induction and a further half of this dose at the time of dilation of cervix; or thiopentone $5 \mathrm{mg}$ per $\mathrm{kgm}$ and 70 per cent nitrous oxide with oxygen with a further onethird of the thiopentone induction dose given when cervix was dilated.

All patients received as premedication $10 \mathrm{mg}$ of dehydrobenzperidol one hour prior to surgery. No other agent was used prior to, during or after the procedure. The patients did not receive any information from doctors or nurses of the type of anaesthetic agent or the possible post-anaesthetic psychomimetic disturbances. After surgery the patients returned to the routine recovery-room environment.

On the following day, i.e., 12 to 24 hours after anaesthesia, the patients were interviewed by the anaesthetist. They were questioned about their dreams and their acceptance for future surgery of the anaesthetic they had been given.

\section{Results}

The overall dream incidence after ketamine anaesthesia was 60 per cent, i.e., 30 out of 50 patients. The incidence following thiopentone-nitrous oxide oxygen was 16 per cent, i.e., 8 out of 50 patients dreamed. The incidence of unpleasant dreams after ketamine anaesthesia was 36 per cent, 18 out of 50 patients. Thiopentone-nitrous oxide oxygen was not followed by unpleasant dreams in any patient.

Seventeen of fifty patients anacsthetized with ketamine ( 34 per cent) rejected ketamine as an agent for future surgery. All the patients anaesthetized with thiopentone-nitrous oxide oxygen would accept this anaesthetic in future.

The ratio of dream incidence to patient number was subjected to statistical evaluation utilizing the chi-square test with Yate's modification for small numbers. The results were significant with a $\mathrm{p}$ value of less than 0.001 .

\section{Overall Dream Incidence}

$\begin{array}{lrll}\text { KETAMINE } \quad \text { ANAESTHESIA } & 30 / 50 & \mathrm{P}< & 0.001 \\ \text { THIOPENTONE N.2O - } \mathrm{O}_{2:} & 8 / 50 & \mathrm{P}< & 0.001 \\ & & & \\ & & & \\ \text { Incidence of Unpleasant Dreams } & 18 / 50 & \mathrm{P}< & 0.001 \\ \text { KETAMINE ANAESTHESIA } & & \mathrm{P}< & 0.001\end{array}$

Incidence of Rejections of Same Anaesthetic Again

$\begin{array}{lrll}\text { KETAMINE ANAESTHESIA } & 17 / 50 & \mathrm{P}< & 0.001 \\ \text { THIOPENTONE N.O }-\mathrm{O}_{2} \text { ANAESTHESIA } & 0 / 50 & & \end{array}$




\section{Some Additional Data}

Tabulation of age and weight of the patients, doses of anaesthetic agents administered, and duration of the operations.

KETAMINE ANAESTHESIA

\begin{tabular}{|c|c|c|c|c|}
\hline & Age & Weight & Dose & Duration \\
\hline MEAN & $23.9 \mathrm{yrs}$ & $62.1 \mathrm{~kg}$ & $132 \mathrm{mg}$ & $11.1 \mathrm{~min}$ \\
\hline S.D. & $\pm 5.3 \mathrm{yrs}$ & $\pm 11.9 \mathrm{~kg}$ & $\pm 39.4 \mathrm{mg}$ & $\pm 2.9 \mathrm{~min}$ \\
\hline \multicolumn{5}{|c|}{ THIOPENTONE $\mathrm{N}_{2} \mathrm{O}-\mathrm{O}_{2}$ ANAESTHESIA } \\
\hline & Age & Weight & Dose & Duration \\
\hline MEAN & 24.3 & $60.4 \mathrm{~kg}$ & $391.8 \mathrm{mg}$ & $11.6 \mathrm{~min}$ \\
\hline S.D. & \pm 6.0 & $\pm 9.7 \mathrm{~kg}$ & $\pm 76.7 \mathrm{mg}$ & $\pm 3.8 \mathrm{~min}$ \\
\hline
\end{tabular}

\section{Discussion and Conclusion}

The mental disturbances following anaesthesia could be separated into two groups. The first kind, patients experienced before awakening. In most instances their content was not related to the hospital environment. Therefore one may refer to this group of mental disturbances as dreams.

The second group of mental disturbances was experienced by ketamine patients only. This occurred after the patient became aware of the recovery-room environment. They were misinterpretations of the surroundings and were entirely hospital related. These mental disturbances can be classified as illusions.

Our results confirm previous reports of a high incidence of dreaming and illusions after ketamine anaesthesia. These dreams were intensely colourful, highly impressive, of abstract or concrete content, and frequently unpleasantly disturbing to the patient.

In contrast, dreams following thiopentone $\mathrm{N}_{2} \mathrm{O}-\mathrm{O}_{2}$ anaesthesia were unimpressive and not disturbing. Recollection of these latter dreams by patient was poor 12 to 24 hours after anaesthesia.

Dehydrobenzperidol has been reported to minimize psychomimetic disturbances after ketamine, and has been advocated as a premedicant drug. ${ }^{10}$ However others have felt that dehydrobenzperidol increases preoperative anxiety. ${ }^{11}$ Our observation is that this agent does little to decrease psychomimetic disturbances after ketamine anaesthesia. Sixty per cent of the total group of patients had psychomimetic disturbances and 34 per cent of the same group had an unpleasant psychological experience. These figures are comparable to those reports in which patients had ketamine anaesthesia without any tranquilizer premedication.

Unpleasant dreams and illusions occurred only in ketamine patients. All patients except one rejected ketamine as anaesthetic for future surgery as a result of this unpleasant experience. These findings contrast with those of Garfield et al. ${ }^{4}$ Their patients dreamed both pleasant and unpleasant dreams after ketamine anaesthesia. Only a few of their patients, however, had objections to accepting ketamine as an 
anaesthetic agent in the future. The explanation may rest with the selection of patients. Garfield's patients were soldiers whose corrective surgery was for conditions which carried no socially objectionable stigma. Our group of young women, who had decided to terminate pregnancy, exposed themselves to psychological stress, based on the still unaccepted status of abortion. This psychological stress in our patients together with ability of ketamine to stimulate the limbic system may have led to an additive stimulating effect of the latter part of the nervous system, resulting in a high incidence of unpleasant dreams and illusions. ${ }^{1:}$

Our conclusion is that ketamine is a poor choice for anaesthesia in patients who come for termination of pregnancy. Thiopentone-nitrous oxide anaesthesia is still preferable.

\section{RÉSUMÉ}

Deux méthodes d'anesthésie différentes ont été utilisées alternativement chez 100 malades consécutives subissant un avortement thérapeutique. Les unes ont reçu $2 \mathrm{mg} /$ kilo de Kétamine en induction, avec répétition de la moitié de cette dose au moment de la dilatation du col. Les autres ont reçu du Protoxyde d'azote à 70 pour cent après une induction au Thiopenthane $(5 \mathrm{mg} / \mathrm{kilo})$; un tiers de la dose d'induction était répété au moment de la dilatation du col.

Dix mg de Dropéridol furent administrés à toutes les patientes une heure avant l'intervention. Les malades furent toutes revues 12 à 24 heures après l'anesthésie.

Cet interview a confirmé les conclusions d'autres auteurs, à savoir l'incidence élevée ( 60 pour cent) de rêves désagréables, ( 33 pour cent) d'hallucinations après administration de Kétamine.

Ces chiffres ressemblent à ceux rapportés après administration de Kétamine chez des malades n'ayant pas reçu de prémédication.

Une malade sur trois s'objectait à recevoir à nouveau le même genre d'anesthésie en cas d'anesthésie future. Par ailleurs, toutes les malades anesthésiées au Thiopenthane, Protoxyde, avaient gardé un bon souvenir de leur anesthésie et étaient disposées à recevoir à l’avenir le mème type d'anesthésie.

\section{REFERENCES}

1. Corssen, Guenter, Miyasaka, M., \& Domino, E.F. Changing concept in pain control during surgery. Dissociated anaesthesia with $\mathrm{Ci}$. 581, a progress report. Anaesthesia \& Analgesia CR. 47: 746-759 (1968).

2. Clarke, R.S.J., Knox, D.W.D., \& Dundee, J.W. The effect of dosage and premedication on the action of ketamine. British Journal of Anaesthesia 42: 799 (1970).

3. Galloon, S. Ketamine for dilatation and curettage. Canadian Anaesthetists Society Journal 18: $601(1971)$.

4. Garfield, J.M., Garfield, F.B., Gilbert Stone, J., Hopkins, D., \& Johns, L.A. A comparison of psychological responses to ketamine and thiopentone $\mathrm{N}_{2} \mathrm{O}-\mathrm{O}_{2}$ halothane anaesthesia. Anesthesiology 36: 329 (1972).

5. Knox, J.W.D., Bovill, J.G., Clarke, R.S.J., \& Dundee, J.W. Clinical studies of induction agents - Katamine. British Journal of Anaesthesia 42:875 (1970).

6. Sadove, M.S., Hatano, S., Zahed, B., Redhin, T., Arastounejad, P., \& Roman, Y. Clinical study of Droperidol in the prevention of the side effects of ketamine. Anaesthesia and Analgesia CR. 50: 388-393 (1971). 
7. Bryce, D.D., Hetherington, R.R., \& UTting, J.E. A simple study of awareness and dreaming during anaesthesia. British Journal of Anaesthesia 42; 535-542 (1970).

8. Harkis, T.J.B., Bryce, D.D., Hetherington, R.R., \& UtTing, J.E. Dreaming associated with anaesthesia. British Journal of Anaesthesia 43: 172-178 (1971).

9. Crawfond, S. Awareness during operative obstetrics under general anaesthesia. British Journal of Anaesthesia 43: 179-182 (1972).

10. Becsey, L., Malamed, S., Radnay, P., \& Foldes, F.F. Reduction of psychomimetic effects of ketamine by Droperidol. Anesthesiology 37: 536-542 (1972).

11. Ellis, F.R. \& Wilson, J. An assessment of droperidol as a premedication. British Journal of Anaesthesia 44: 1288 (1972)

12. Pender, J.W. Dissociated anaesthesia. J.A.M.A. 215: 1126-1130 (1971). 